\title{
The Anxiety of Abundance: William Stanley Jevons and Coal Scarcity in the Nineteenth Century
}

\author{
NUNO LUIS MADUREIRA
}

Lisbon University Institute-ISCTE

Av. ${ }^{a}$ das Forças Armadas, 1649-026 Lisboa, Portugal

Email: nuno.madureira@iscte.pt

\begin{abstract}
Right from the outset, the adoption of mechanical machinery, railways, steamships and long distance communications was accompanied by growing concerns about the possibility of running out of coal. This article examines three main issues: firstly, what triggered the scarcity fear, given that the historical period was one of rising prosperity with no foreseeable shortages in sight; secondly, what actually went wrong with the coal supply vision given so many of the forecasts associated with the scarcity thesis were not borne out by reality; and thirdly, by what means did the nineteenth century coal debate shape environmental thinking and provide crucial concepts that have persisted through to the present (the rebound effect, probable reserves and environmental limits to growth). A close look is taken of the work of William Stanley Jevons, whose ideas became a milestone in the debate on the depletion of natural resources. The overall conclusion points out that the looming uncertainty of the 1860 s and 1870 s paved the way for new probabilistic assessments of mineral patrimony.
\end{abstract}

\section{KEYWORDS}

William Stanley Jevons, fossil fuel depletion, geology, natural resources, coal

The dawning of industrialisation has not only been identified with the age of coal, steam and iron, but also as the moment when the modern concept of 'scarcity' took shape. Applied to natural resources, 'scarcity' translated the awareness that the path undertaken by modern economic development increasingly relied on finite resources. Far from being any smooth process, industrial-led growth had 
to face up to the problem of diminishing natural endowments, particularly those vital to fuelling the economy. By the third quarter of the nineteenth century, it had become clear that a new environmental equilibrium was emerging. Puzzling as it may seem, the fact is that the adoption of mechanical machinery, railways, steamships and long distance communications was accompanied by growing concerns about the possibility of running out of coal. Though this merely represented one eventuality, it nonetheless shook the foundations of society. The scarcity of the energy source upon which most modern technologies depended foreshadowed a stormy future and an uncertain present.

The historical period characterised by the fear of coal shortages (1861-1880) has mostly been analysed through the eyes of William Stanley Jevons, a remarkable British thinker whose 1865 book The Coal Question shifted the terms of the debate with fresh ideas. According to Jevons, the spontaneous logic of the price mechanism steps up the pace of coal depletion in a market economy. The problem faced by mankind is therefore geological from its inception but economic in its consequences and course of action: the way resources are used matters as much as the actual amount of the resources. This perspective challenged existing views by putting increasing stress on the uncertainty brought about by ever growing demand. Authors like Peter Sieferle and Bert Mosselmans have pointed out that Jevons translated the classical concepts of natural limits to development, imposed by the finite nature of land resources, into the environment of fossil fuel usage. ${ }^{1}$ This was an epochal shift that represented a dislocation of the core engine of growth from reproducible and universal productive factors towards exhaustible and unevenly distributed factors. And since Great Britain was at the forefront of other nations in terms of fossil fuel production, internal consumption and exports, its economy was naturally more exposed to the threat of depletion. Jevons did not devise any escape from scarcity given the increasing pressures brought about by population growth, increasing affluence and consumption and technological progress. He maintained that whilst land-based economies could attain a stationary state once the marginal return of land decreased to zero, coalbased economies were doomed to fall-off when the economically exploitable coal reserves were depleted. ${ }^{2}$ The message was stark and alarming.

Historians of economic thought have furthermore highlighted how the dilemma of natural resource exhaustion had become a stepping stone for neo-

1. Bert Mosselmans, 'Reproduction and scarcity: the population mechanism in classicism and in the Jevonian revolution', The European Journal of the History of Economic Thought 6 (1999): 34-57; Rolf Peter Sieferle, The Subterranean Forest. Energy Systems and the Industrial Revolution (Cambridge: The White Horse Press, 2001), pp. 197-202.

2. Classical economists focus their attention on the special natural resource of land; a resource whose stock cannot be increased or decreased, but on which a rent is paid. Since the limitedness of land pushes down the rate of profit, the economy is viewed as tending towards a stationary state. See Marianna Belloc et al., 'Technology and the environment in the history of the economic thought', International Journal of Global Environmental Issues 8 (2008): 311-34. 
classical economics, leading Jevons to redefine production in normative terms: in a world threatened by energy shortages, industrial manufacturing had to be redesigned in order to extract the optimal utilisation of scarce resources. ${ }^{3} \mathrm{Ef}-$ ficiency was the only possible way out. Greater value and more energy could be obtained from existing coal reserves even though this would not be enough to turn Great Britain off the road to exhaustion. In some sense, only secondbest solutions seemed attainable. No wonder that, under these circumstances, the notion of optimal allocation of scarce resources left most contemporaries uneasy and increasingly pessimistic.

The following pages place the debate back in its historical context by drawing attention to another stream of thought that openly clashed with the scarcity thesis. This stream was constituted by professional geologists, amateur geologists, technical experts assembled into local scientific associations and colliery owners. For them, scarcity was inconceivable. Irrespective of upcoming trends, the risk of depletion could be positively counteracted through appropriate actions in the domain of resource conservation, waste abatement, the mining of ever-deeper coal seams and the discovery of untouched sources. Such a combination of conservationism and technological optimism managed to jointly call for demand side restraints and supply side inventiveness. In practical terms, they advocated stronger regulation of productive activities and consumption patterns together with improvements in geological knowledge and mining technology so as to bring more coal onto the markets and extend the life of reserves. Instead of a theoretical background framed by ever-increasing needs, fixed natural resources and irredeemable market mechanisms (Jevons), conservationists preferred to posit fixed needs (needs flattened over a plateau of coal consumption), expanding natural resources and pro-active human action.

In crafting a link between geology and economics, this article aims to discuss the historical meanings of the 'scarcity' concept which has wielded a large theoretical influence in the human sciences. Three main issues are addressed: first, what triggered the scarcity fear given that the historical period was one of prosperity with no shortages in sight; second, what went wrong with the vision of the exhaustion of coal supplies, since many of the forecasts associated with the scarcity thesis were not borne out by reality; and third, by what means and to what extent did the nineteenth century coal debate shape environmental thinking and provide crucial concepts that have lasted down to current days (the rebound effect, probable reserves and environmental limits to growth).

It is well known that in style, content and authorship, the coal question was essentially a British affair. However, British thinkers and British institutions carefully grounded their options and ideas on a close survey of world competition

3. Philip Mirowski, More Heat than Light. Economics as Social Physics, Physics as Nature's Economics (Cambridge: Cambridge University Press, 1989), pp. 254-265; Michael V. White, 'In the Lobby of the Energy Hotel: Jevon's Formulation of the Postclassical Economic Problem', History of Political Economy 36 (2004): 227-71. 
and world technological development. So intensive was this data-searching that British decision makers quite often had at their disposal better information on coal issues than the authorities from the distant countries where the information had been collected. ${ }^{4}$ Starting in 1866 , embassy secretaries and consuls engaged in a frenzy of activity gathering every scrap of coal related information, from Japan to Argentina. ${ }^{5}$ On occasion, there were even special consular surveys dedicated to single nations (such as Belgium and the United States). While concern over coal supplies may have been by and large a British affair, it was nonetheless tackled with knowledge that spanned the world. It seems therefore methodologically advisable to adopt the same scope and analyse British concerns over coal within their worldwide context.

\section{RECOVERABLE COAL AND HIDDEN COAL}

Up to the nineteenth century, detailed knowledge about coal reserves was mainly in the hands of mine owners, merchants and colliery overmen, sometimes augmented by information gleaned from antiquarian writers. These were the right people to ask when trying to assess how much coal could still be recovered across a whole region. Their knowledge was based partly on direct or indirect experience from excavation in its most basic form, from outcrops, or more generally, from information derived from the removal of the overlying rock and soil (overburden) and the rate at which coal seams were thus exposed. One way or the other, they undoubtedly knew which were the shallowest and easiest seams to explore. Likewise, they could foresee how much of the mineral could be removed and how long it would take to exhaust the pits. The calculation itself was conveniently made by rule of thumb based upon the prevailing British assumption that a cubic yard of underground coal yielded a ton in weight. ${ }^{6}$ To reach a final figure, particular consideration was given to the thickness of the seams and the surface area beyond which the mining of coal was no longer judged profitable. Ultimately, sinking deeper shafts, with greater costs of excavation, haulage and drainage set a ceiling for the recovery of underground stocks. Deeper mining was undertaken only when the thickness of lower seams or higher quality coal justified the extra costs.

Hence, experience of mining in progress painted a good picture of the local potential. However, what about undiscovered coal fields? And the potential of

4. See for instance: House of Commons, Parliamentary Papers, Reports by Her Majesty's Secretaries of Embassy and Legation on the Manufactures, Commerce, etc., of the Countries in which they Reside. Part I- V., London: Harrison and Sons, 1875.

5. Reports Received from Her Majesty's Secretaries of Embassy and Legation on Coal, House of Commons, Parliamentary Papers (London: Harrison and Sons, 1866), 1867.

6. William Stanley Jevons, The Coal Question. An Inquiry Concerning the Progress of the Nation, and the Probable Exhaustion of Our Coal-Mines (1865; reprint, London: Macmillan and Co., 1866), p. 88. 
more distant regions? In this respect, common knowledge up to the nineteenth century seems to have been based on only exposed areas of coal fields without considering the possibility that they might continue beneath the cover of later deposits. The disregard for new fields where 'hidden coal' might be available was particularly significant in continental Europe and in Russia, reflecting a market environment in which the industry spread step by step through to the 1860s. Regions like the Upper Silesian-Moravian Basin (a zone held by Germany) were consequently locked into a geographical pattern that was established at the dawn of the nineteenth century with all shafts lying at a distance of no more than about a mile beyond the margin of the exposed coal field. In spite of the mounting demand for coal for iron smelting, the pattern in the Silesian-Moravian Basin remained unchanged for at least another sixty years?

Indeed, by the early nineteenth century, coal mining was nothing but a minor activity outside Britain and Belgium, hindered by enclave economies, small scale operations and companies with demand restricted to the immediate vicinities. In these circumstances, an estimation of the stock of fossil fuels was built into the very process of getting the coal fields up and running. Reserves certainly mattered, and they mattered above all to mining people.

A new approach towards the potential of undiscovered mineral basins, based on the commercial geological prospecting of coal resources, began to surface in the 1820s. This move into the unknown was both offensive and defensive. In the United States, it was on the offensive in seeking out new and flourishing business opportunities. On the private side, the discovery of coal near Pittsburgh aroused interest among economic boosters and land speculators from the East who hired teams of geologists and civil engineers in the 1820 s to compile scientific reports on George's Creek Valley. ${ }^{8}$ Geological reports were important in attracting the attention of interested investors, as well as providing information blueprints for decisions. In the public domain, state legislatures began taking the same steps a few years later, hiring geologists to identify rich deposits of mineral resources. In cases where it was thought large coal basins might be unveiled, for example in Pennsylvania and Illinois, the authorities went so far as to instruct geologists to map the coalfields. However, in spite of the state's engagement in sponsoring the costs of obtaining information, the results from this geological prospecting and investment front were meagre. ${ }^{9}$

Whilst Americans attempted to push their control over the territory further and seize gilded opportunities (gold was also an object of research), the British displayed a much more defensive stance since their primary goal was to find

7. Norman J.G. Pounds, 'The Spread of Mining in the Coal Basin of Upper Silesia and Northern Moravia', Annals of the Association of American Geographers 48 (1958): 149-163.

8. Geoffrey L. Buckley, 'The Environmental Transformation of an Appalachian Valley, 1850-1906', Geographical Review 88 (1998): 175-198.

9. Sean Patrick Adams, 'Promotion, Competition, Captivity: The Political Economy of Coal', Journal of Policy History 18 (2006): 74-95. 
untapped natural resources able to replace those already exhausted. Although the recruitment of geologists to carry out regional surveys was a major innovation in the 1830 s - an innovation shortly to prove inherent to the concept of 'reserves'the driving force behind British endeavours was geological pessimism. Surveys were therefore carried out in regions where the coalfields had long passed their maturity and were on the verge of exhaustion by the early nineteenth century. ${ }^{10}$ These were worrying cases in which the inescapable decline in production was already threatening local prosperity and social equilibrium. Albeit exceptional and largely outweighed by the growing production of fresh, expanding regions, such as South Wales, Yorkshire, East Midlands and Scotland, the coalfields on the verge of exhaustion became the focus for public policy. Sooner or later, the story would certainly be repeated in other regions. Hence, the disturbing question was, just how soon? Given the lack of up-to-date knowledge on the stock of British solid fossil fuels, ${ }^{11}$ isolated cases of depletion which statistically held little current relevance were perceived as on the verge of snowballing into a frightening future.

Geological knowledge broadened the prospects for coal availability from that existing to future supplies. Regional surveys based on the mapping of geological structures from coal basins were later undertaken in continental Europe: the geologists Jakob (1846) and von Dechen (1953) assessed the evenness of the Ruhr basin and estimated its proven reserves while Jules Gosselet studied the coal basin of Belgium (1860) and established the likelihood of finding coal in Northern France, along the Pas-de-Calais southern border (1863-1873). ${ }^{12}$

Overall, these regional surveys proved highly instrumental in efforts to attract investment and chart business opportunities. Naturally, the transposition of these experiences into a national plan entailed a much larger scale investigation with the involvement of and financing by central states, the recruitment of teams of geologists and the redefinition of survey methodologies and logistics. By the 1860 s and 1870 s, governments decided to advance, thus opening the way for the first national geological surveys.

With the institutionalisation of data searches over entire territories, the remnants of the amateur tradition began to fade away and with them the liberal practice of geology. Even in Britain, where the gentlemanly way of researching 'earth sciences' had strong social roots, the combined effects of both professionalisation, through the survey, and greater university access changed the

10. Roy Church, The History of the British Coal Industry (Oxford: Clarendon Press, 1986), pp. 8-9.

11. Several estimates undertaken between 1792 and 1860 on the British Isles predicted that coal reserves would last for 300 to 400 years. See Sieferle, The Subterranean Forest, pp. 188-191; 'Duration of the Supply of Coal', 29 May 1866, The Leeds Mercury, Issue 8785.

12. Marcel Gillet, Les Charbonnages du Nord de la France au XIXe siècle (Paris: Mouton, 1973), pp. 64-69; M. Maurice Baumont, La grosse industrie allemande et le charbon (Paris: Gaston Doin, 1928), pp. 38-9. 
profile of this scientific field. ${ }^{13}$ No less important was the fact that the move towards the national survey occurred in a context where the local coal economy had already been replaced by regional market integration, rising demand and external trade, the interdependence of coal mining and railway companies, and concentration through merging and incorporation. ${ }^{14}$ Industrial progress had enhanced the value of this asset, raising its importance when prioritising the natural resources to be mapped.

In the United States Congress, supporters of the decision to undertake the US Geological Survey (1879) underscored the strategic role of coordinating the geological mapping of mineral resources in the vast trans-Mississippi region, and particularly in the largely unknown region west of the Rocky Mountains. Moreover, specific instructions were issued regarding coal mines. ${ }^{15}$ The final results published in the 1880s presented a threefold view of the same area: one map entitled 'Areal Geology' outlined the surface distribution of the various rock masses; another unveiled the 'under geology' called 'Structure Sections'; and a third disclosed the rock masses known to be of economic importance due to their yield of iron, coal, gold, or other metals. From this contextual perspective, 'economic geology' could be associated to the composition, structure, properties, and history of the planet's physical material, thereby becoming a matter for professional expertise. ${ }^{16}$

Compared with other inventories of US natural resources, such as iron ore and gold, the coal survey was often admired as the most accurate assessment ever made. In 1909, it was said 'that future discoveries of coal outside of the limits indicated for existing fields are not likely to exceed one per cent of the total known supply; and future investigations are likely to diminish rather than increase the estimates of the quantity available within these limits'.${ }^{17}$ This fact, associated with the large reserves found, drove nineteenth century conservationist thinking, later entangled with political progressivism, to emphasise timber, forest products and oil ${ }^{18}$ as the key resources to be preserved and used, and

13. Roy Porter, 'Gentlemen and Geology: The Emergence of a Scientific Career, 1660-1920', The Historical Journal 21 (1978): 809-836; Jean G. O’Connor and A.J. Meadows, 'Specialization and Professionalization in British Geology', Social Studies of Science 6 (1976): 77-89.

14. Sam H. Schurr and Bruce C. Netschert, Energy in the American Economy, 1850-1975 (Westport-Connecticut: Greenwood Press, 1975); Church, The History of the British Coal Industry; John G. Clark, The Political Economy of World Energy (New York, Harvester Wheatsheaf, 1990), pp. 16-28.

15. Adams, 'Promotion, Competition, Captivity': 90.

16. Marcus Baker, 'The U. S. Geological Survey', The Geographical Journal 6 (1895): $252-260$.

17. Henry Gannett, Report of the National Conservation Commission. February, 1909 (New York: Arno Press, 1972), p. 96.

18. Samuel P. Hays, Conservation and the Gospel of Efficiency (Cambridge, Massachusetts: Harvard University Press, 1959); Martin V. Melosi, Effluent America, Cities, Industry, Energy and the Environment (Pittsburgh: University of Pittsburgh Press, 2001), pp. 23-48; 
furthermore to be fairly distributed, preventing 'monopolization in the hands of a few favored interests' ${ }^{19}$. To counteract the voracious depletion of natural resources and particularly the lack of forest protection, some like-minded men in Chicago set up the first contemporary environmental organisation, the American Forestry Association. Helped by hunting and fishing clubs, the Association gave voice to the idea that the common good of renewable natural resources was greater than their private commercial benefits. Besides taking direct action, such as gathering information and raising public awareness, the movement called for a more active federal position to encourage tree planting and curtail claims from the lumber industry. Furthermore, they also worked on plans to establish forestry reserves and parks. ${ }^{20}$ In policy terms, however, coal was off the hook.

Unlike the business-oriented and later citizen-oriented perspective held by the US federal government as well as the fledgling environmental movement, the British elites saw the survey as a central state concern or, to be more precise, as a key issue for the Empire's political economy. By the 1860s, apprehensions about depletion had already made themselves felt in the House of Commons and prompted a blistering debate. The debate had been triggered by the signature of the Cobden-Chevalier Treaty, which forbade both the prohibition of and duties on coal trading between France and Britain. The arguments as to whether favouring French coal imports could hit British interests and thereby contribute towards the exhaustion of its mines divided the assembly. Fundamentally, no one could be truly sure that the liberalisation of trade would not jeopardise a commodity that had become the mainstay of the Empire, of industrial supremacy and economic competitiveness. ${ }^{21}$

There were clear priorities for data collection and this explains why the British Geological Survey of 1861 focused exclusively on coal formations. Run by the geologist Edward Hull, the account of natural resources not only ascertained the recoverable coal available through direct surveys in each mining region, but also advanced a forecast of the likelihood of finding undiscovered 'hidden coal' reserves. Thus, systematic assessment added the concept of unknown resources to the estimation of those proven. Edward Hull resorted to mapping the geological data on each rock system across the country to assess the likelihood of finding valuable untapped seams. After considering other factors, the geologist came up

John G. Clark, Energy and the Federal Government. Fossil Fuel Policies, 1900-1960 (Chicago: University of Illinois Press, 1987); Diana Davids Olien and Roger M. Olien 'Running Out of Oil: Discourse and Public Policy, 1909-1929', Business and Economic History 22 (1993): 36-66.

19. James R. Garfield, 'Address', in Proceedings of a Conference of Governors in the White House Washington D.C., ed. by Newton C. Blanchard (Washington: Government Printing Office, 1909), p. 183.

20. Hays, Conservation and the Gospel of Efficiency, pp. 26-28.

21. Lozé (ed.) Charbons Britanniques et leur épuisement (Paris: Libraire Polytechnique Ch. Bérangeur éditeur, 1900); 'The Treaty and the Coal Question', 28 February 1860, The Caledonian Mercury, Issue 21973. 
with the figure of 932 square miles in England and Wales worth exploring for more coal. Though potential extraction was not fully quantified, this approach ensured an extra buffer against the menace of sudden and swift depletion ${ }^{22}$.

In the end, the recoverable resources as assessed by the Geological Survey for England, Wales and Scotland amounted to about 80,000 million tons of coal, which, at the rate of production in the late $1850 \mathrm{~s}$, would last for 1,100 years. Moreover, the potential for further discoveries in untapped seams further reinforced the conclusion that 'for many generations to come the mineral resources of England [were] capable of bearing any drain to which they [could] possibly be subjected either for home or for foreign consumption'23

A clear answer had been given. Coal was sufficiently abundant to remove any shadows that might loom over the forthcoming decades: Britain could expect to hold onto its lead in manufacturing, in trade and in sea power. During this process, the urgency to restore confidence made geologists deploy robust methods and forceful means (with 57 geologists employed in the 1860s) ${ }^{24}$ to estimate natural resources; methods soon to be emulated in other coal producing nations. Besides the pioneering nature of the 1861 Geological Survey, two points stand out as scientific benchmarks: first, the endeavour to gauge resources beyond what had previously been acknowledged through commercial mining operations. The survey was not just a sum of the resources existing in coal mines; it also sought to draw the map of probable geological occurrences. Secondly, due to Britain's head start, the accumulated technological and scientific expertise allowed geologists to set the threshold of economically recoverable reserves at a depth of 4,000 feet (1,220 metres), provided the seams were two feet thick, which meant that, despite the extra costs incurred by extracting coal at 4,000 feet, the coal would still likely sell at a competitive market price. ${ }^{25}$

Even though this threshold was publicly criticised as conservative, mostly by opponents of the scarcity thesis, people in the trade knew very well that mining at 4,000 feet deep, at a profit, was an achievable assumption even if only in the near future. The deepest mine in Britain at that time had reached 2,100 feet and reached down to 2,370 feet a decade later. In continental Europe, working coal had been carried out at a depth of 2,760 (in the Austro-Hungarian Empire) and 3,000 feet (in Belgium). ${ }^{26}$ Reflecting on the subject, a British

22. Edward Hull. The Coal-fields of Great Britain, their History, Structure, and Duration. With notices of the coal-fields of other parts of the world (London: Edward Stanford, 1861), p. 138.

23. Hull. The Coal-fields of Great Britain, p. 139.

24. O'Connor and Meadows, 'Specialization and Professionalization': 80.

25. Gregory Clark and David Jacks, 'Coal and the Industrial Revolution. 1700-1869', European Review of Economic History 11 (2007): 39-72; Roy Church, The History of the British Coal Industry, p. 180.

26. Joseph Hodsworth, On the Extension of the English Coal-fields beneath the Secondary Formations (London: R. Middleton, 1866); Report of the Commissioners Appointed to Inquire into the Several Matters Relating to Coal in the United Kingdom, House 
businessman remarked that 'with our present experience and at anything like our present cost', 'we are only justified in expecting to penetrate to a depth of some 2,700 feet' ${ }^{27}$ All in all, it took about forty years for these expectations to materialise. Getting nearer the threshold of 4,000 feet (the limit of 3,500 feet deep was breached in 1902 at a single colliery at Rams Mine, Pendleton) was only possible through a protracted process involving a full range of technologies. To obviate the difficulties created by increasing pressures and increasing temperatures, miners had to install new pipe systems for watering and winding and fan engines for ventilation, adopt the long-wall method for extracting coal, introduce compressed air machines for hauling and coal-cutting and enhance the maintenance of roadways and airways. ${ }^{28}$

In light of this evidence, the minimum that can be said about the $1861 \mathrm{Geologi}$ cal Survey is that it acted as a harbinger of various technological advances so as to account for 'reasonably assured reserves', rather than for the straightforward criteria of 'proved reserves in place'. ${ }^{29}$ Edward Hull's figures were, from this point of view, clearly optimistic as they tend to reflect a forward-looking perspective along with great confidence in British technological accomplishments.

In any case, the adoption of systematic geological criteria made the concept of exploitable resources dependent on technical-economic costs, rather than on the direct physical measurement of coal seams. And the dynamic upshot of this development was that the amount of reasonably proven coal reserves was expected to increase in tandem with changes in best-practice economicorganisational technology. Its stocks therefore came to be viewed as a drifting edge, turning the basic uncertainty surrounding depletion into a probabilistic classification of natural resources.

\section{GEOLOGICAL OPTIMISM AND ECONOMIC PESSIMISM}

The Geological Survey brought the parliamentary season of open apprehension to a sudden halt. The awesome forecast of a supply guaranteed for 1,100 years had relegated the problem of depletion to a few pits marginally located in

of Commons, Parliamentary Papers, (London: George Edward Eyre and William Spottiswoode), 1871, Vol. I, pp. 81-2.

27. 'The Coal Supplies of England', The Derby Mercury, 17 January 1872, Issue 8218.

28. Royal Commission on Coal Supplies, First Report of the Royal Commission on Coal Supplies. Minutes of Evidence, and Appendix, House of Commons, Parliamentary Papers (London: Wyman \& Sons, 1903) Vol. II.

29. Only the category of 'proved reserves in place' is currently accepted as a valid category by the World Energy Council. It describes the 'total identified and carefully measured amount of coal estimated to be in place in known deposits as revealed by outcrops or by drilling or mining and by detailed sampling to establish its rank and quality; these deposit have been assessed to be exploitable under current or expected local conditions and using currently available mining technology'. Amos Salvador, Energy: A Historical Perspective and 21st Century Forecast (Tulsa: American Association of Petroleum Geologists, 2005), p. 82. 
pioneering coal fields. However, just as everything seemed settled, anxiety was actually raised another notch with renewed arguments highlighting the fragility of Britain's position.

No one was questioning Edward Hull's work or the data assembled by the Geological Survey as this problem went beyond geological estimations. Just two years after the figure of 80,000 million tons of reserves had been released, a prominent industrialist, inventor and patron of science, William George Armstrong, again called for changes in public policy in a speech made on becoming President of the British Association for the Advancement of Science. He argued that depletion would not be the result of the scarcity or abundance of underground seams, but of a dramatic increase in consumption. This turnaround in the understanding of the 'coal question' marked a shift from geologic to economic factors. Like his scientific peers, Armstrong accepted the account given by the Geological Survey but complemented it with new forecasts based on the premise made from extrapolating the average growth recorded over the previous period (1853-1861) to find that coal consumption would increase by 2.75 million tons per year. If this were true, coal would last only for 212 years and the British government ought to sound the alarm yet again. Moreover, the best coal for industrial applications, and the least expensive to extract, would have gone long before the exhaustion deadline loomed, something for which the phrase 'commercial exhaustion' was later coined. ${ }^{30}$

The security interval of coal supply was consequently pulled forwards: and 212 years did not exactly mean 212 years of prosperity. Before depletion, scarcity would work its evils though the mechanism of rising costs and price increases. This, in turn, would cause Britain's position in world trade to be taken by the emerging power of the United States, which was endowed with vast untapped reserves of good bituminous coal that would be much more competitive than British coal. Perhaps the 212 geological years of reserves would ensure less than 100 years of Britain's economic supremacy. It is worth noting here that Armstrong, like other British writers ${ }^{31}$ equated industrial ascendancy with coal. Within this line of reasoning, the moment of British decline was moved from the distant future of physical geologic reserves to the more immediate mid-term of technical-economic profitability. Though the end was not in sight, the beginning of the end was close - at least, close enough to revive the debate.

After Armstrong had lent his weight as a successful entrepreneur, leading scientist and mine owner to the cause of protecting natural resources, the patriotic call attracted growing support among politicians, geologists and economicallyminded politicians. In the ensuing years, several spokesmen appealed for a more active government position towards spoilage and waste in manufacturing and households, while others suggested reversing free trade policies and placing

30. William George Armstrong, Report of the 33d Meeting of the British Association for the Advancement of Science (Newcastle-upon-Tyne, BAAS, 1863), pp. li-lxiv.

31. Lozé, Charbons Britanniques et leur épuisement, pp. 851-856. 
constraints on coal exports. ${ }^{32}$ Either way, the general feeling was that an age of scarcity could not be avoided.

It was in 1865 that an almost unknown author entered the debate 'uninvited' and with no previous experience in related matters. William Stanley Jevons was in effect far from the main arenas of political and academic dispute when he decided to enter the debate on the coal question. For much of his life he had thrived on adversity and it was the stubborn ambition of pursuing an academic career in England that led him to abandon a lucrative position as assistant assayer in Sydney, Australia and come to London to complete undergraduate and Master's degrees. During his studies, Jevons set himself the goal of creating a new synthesis of philosophy, logic, political economy and mathematics. However, his hopes of a top academic calling were soon dashed: his first essays got a cold reception and his appointment as tutor at Owens College, Manchester, fell far below his expectations. Consequently, it seems that Jevons turned to the popular subject of coal because his theoretical contributions to political economy had received little attention. ${ }^{33}$

During the summer break of 1864, the Owens College tutor wrote 380 pages of a book entitled The Coal Question: An Inquiry into the Progress of the Nation, and the Probable Exhaustion of our Coal Mines. The decision soon paid off. When the book was distributed the following year, it quickly captured the spotlight and pushed the author into the centre of the public debate. The book gained such success partly because it backed the popular shortage thesis but also because it provided a fresh economic explanation for impending coal exhaustion.

The Jevons point of view challenged established beliefs. Everyone was aware of the improvements in the thermo-dynamic efficiency of steam engines and how they had increased the amount of useful work obtained from any given quantity of coal. Available statistics demonstrated a tenfold rise in the 'returns' provided by the best high pressure steam engines of the 1860 s in comparison with eighteenth century atmospheric engines ${ }^{34}$. Insofar as this path of technological efficiency could yield continuing improvements, Britain would benefit from productive energy-savings to counteract growing demand and the threat of depletion. Thus, the spirit of ingenuity which assured progress with ever less coal created a way of cancelling out the effects of economic growth on natural resources, particularly if other factors also ran in the same direction - for instance, should mounting foreign production slow down the volume of exports. Drawing on this line of reasoning, Edward Hull from the Geological Survey believed that British demand for coal would soon plateau, a view repeatedly

32. Lozé, Charbons Britanniques et leur épuisement, pp. 853-856.

33. Michel V. White, 'A biographical puzzle: why did Jevons write the coal question?', Journal of the History of Economic Thought 13 (1991): 222-42.

34. Jevons, The Coal Question, p. 128.

Environment and History 18.3 
echoed in the press. ${ }^{35}$ And with less consumption, the pace of depletion would slow correspondingly.

The Jevons perspective turned this argument upside down. He stated that it 'is wholly a confusion of ideas to suppose that the economical use of fuel is equivalent to a diminished consumption. The very contrary is the truth ... ${ }^{36}$ $\mathrm{He}$ then reached the paradoxical conclusion that saving energy leads to more energy consumption. Owing to the peculiar formulation of this riddle, it became known as 'Jevons' paradox'.

The key to the argument is efficiency's effects on prices and therefore on profitability and demand. Greater efficiency works economically by lowering the price of energy with two direct consequences: an increase in the profits of trade, thereby attracting more capital into the industrial sector, and a reduction in the price of goods, thus fostering overall demand. Either way, through supply and demand, the net result is a rise in production, thus driving demand for energy: 'If the quantity of coal used in a blast furnace for instance, be diminished in comparison with the yield ... the greater number of furnaces will more than take up for the diminished consumption of each'. ${ }^{37}$ Jevons called this mechanism a direct effect. It becomes 'direct' as the energy savings in branch-specific and commodity-specific sectors prompt further investment in the same branch. As a result, part of the improvement in energy efficiency brought about by technological innovation is offset by the upward shift in production.

The author appears to have found the role of indirect effects even more remarkable. Defined as the 'excitement' induced in other economic sectors by price decreases in a single industrial branch, the importance of these indirect effects tends to increase the level of business interdependency. Although Jevons was not very clear or explicit about the issue, ${ }^{38}$ a reasonable interpretation is that he was primarily thinking about external output effects, for instance, producers making use of cost savings from energy-efficiency improvements to increase output, thereby increasing the consumption of capital, labour and materials, which also require energy (Figure 1: External output effects). He was probably also considering indirect effects of a substitutive kind; in other words, both the energy-efficiency improvements and associated reductions in energy prices lessened the cost of energy-intensive goods in relation to the non-energy-intensive, thereby shifting consumer demand towards the former (Figure 1: Substitution effects). Jevons believed that coal-based technologies would soon wipe out and actually replace the traditional non-fuel-intensive sectors of windmills, animal

35. In fact, the core of his argument, that savings encourage further consumption, was sometimes not fully understood by the press. See 'The Probable Duration of our Coal Fields', 16 May 1866, The Leeds Mercury, Issue 8765; untitled article, 7 May 1866 Glasgow Herald, Issue 8216; 'The Supply of Coal in the United Kingdom', 19 August 1871, Liverpool Mercury, Issue 7355.

36. Jevons, The Coal Question, p. 123.

37. Jevons, The Coal Question, p. 125.

38. Jevons, The Coal Question, pp. 125-127, 135-136, 175.

Environment and History 18.3 
and water power, making Britain, and much of the developed world, ever more dependent on coal reserves.

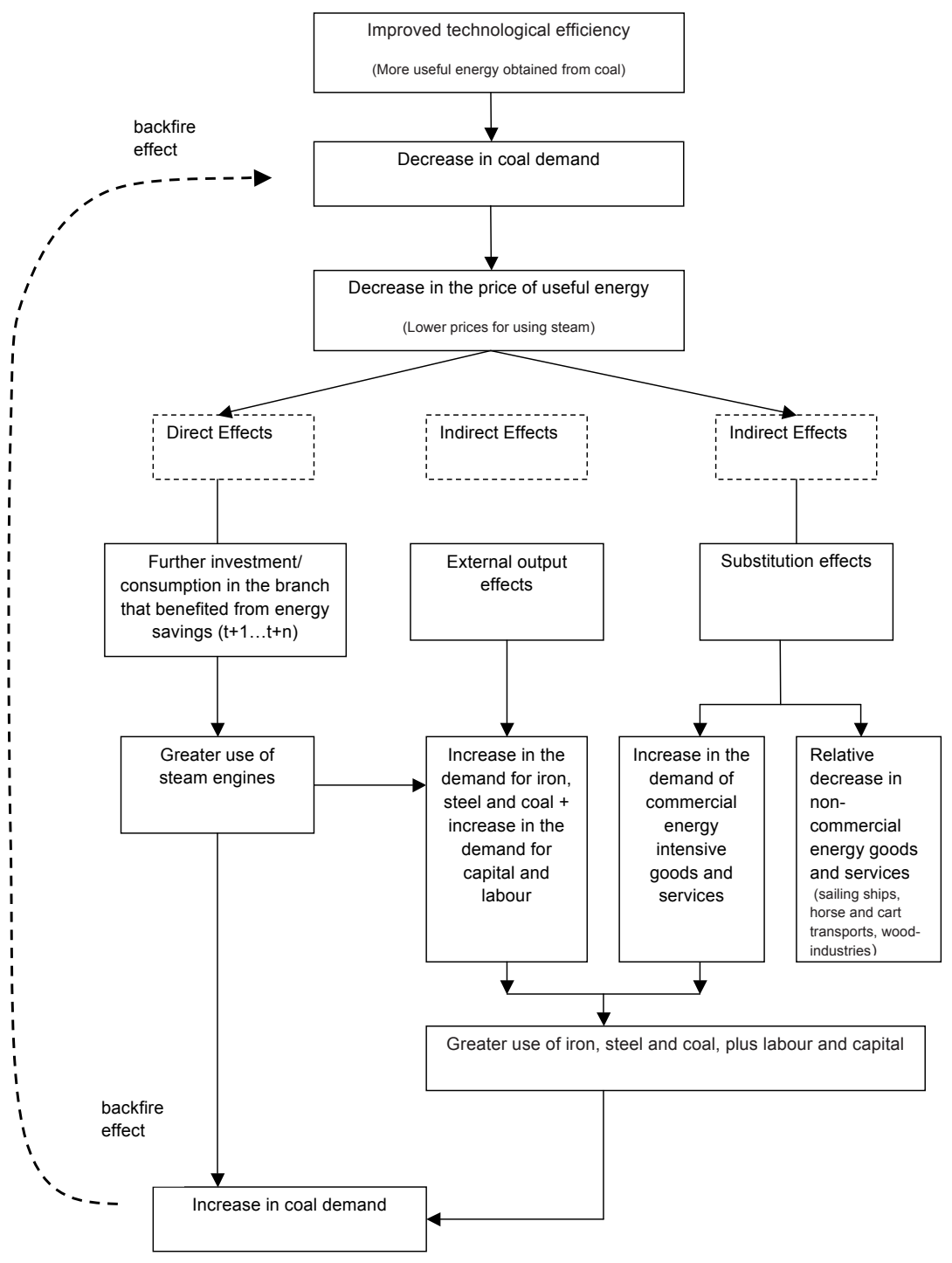

FIGURE 1 . The steam engine and nineteenth century coal consumption according to

William Stanley Jevons (Jevons' Paradox, 1865) 
Again, part of the coal savings induced by technological innovation (for example, generating steam power with less coal - Figure 1) is taken back by the demand-push conveyed through interdependent sectors (making more steam engines requires more iron, steel, workers and capital which, in turn, requires extra coal). What appeared a paradox from a static point of view therefore becomes a consistent and logical explanation within the framework of a dynamic cycle, since the fall in coal consumption occurring at the moment of breakthrough $t$ is formally separated from the rise in coal consumption over the period $t+n$. Due to the feedback loop in Jevons' argument, the 'backfire' phenomenon was later called the 'rebound effect'.

An overall or economy-wide rebound effect represents the sum of the direct and indirect effects and is normally expressed as a percentage of the expected energy savings from an energy-efficiency improvement perspective. Hence, an economy-wide rebound effect of ten per cent means that ten per cent of the potential energy savings are 'taken back' through one or more of the abovementioned mechanisms.

Jevons' argument is grounded on the assumption that the economy-wide rebound effect is always greater than 100 per cent so that the expected energy savings are entirely offset, leading to zero or negative net savings for the economy as a whole. In fact, rebound effects of more than 100 per cent are the backbone of the paradox. Jevons' conviction that this (worst case) scenario was the only admissible outcome in a continuous scale of rebound effects helps to explain why he was seldom seen as the harbinger of a gloomy future. It is worth recalling that the 100 per cent backfire assumption implies that, irrespective of the path taken by technological innovation, greater technological efficiency savings would only contribute to actually stepping up the pace of fossil fuel depletion. ${ }^{39}$

Most of all, Jevons' theoretical arguments still nourish contemporary research 150 years on from his original essay. Discovering the extent of the rebound effect and how it varies with types of energy-usage and the stages of development of particular technologies still remain crucial questions with overwhelming implications for policies aimed at reducing carbon dioxide $\left(\mathrm{CO}_{2}\right)$ emissions and counteracting global warming. ${ }^{40}$ It is worth noticing that if Jevons is right, then encouraging energy-efficiency as a means of reducing carbon emissions would be a counterproductive policy.

39. On the difficulties involved in quantitative estimates of the rebound effects see Steve Sorrell, 'Jevons' Paradox Revisited: The Evidence for Backfire from Improved Energy Efficiency', Energy Policy 37 (2009): 1456-69; Roger Fouquet, Heat, Power and Light: Revolutions in Energy Services (Cheltenham: Edward Elgar Publications, 2008), pp. 274-81; Roger Fouquet and Peter J. Pearson, 'Seven Centuries of Energy Services: The Price and Use of Light in the United Kingdom (1300-2000)', The Energy Journal 27 (2006): 139-78.

40. For a balance see L.A. Greening, D.L. Greene and C. Difiglio, 'Energy Efficiency and Consumption - The Rebound Effect - A Survey', Energy Policy 28 (2000): 389-401; Blake Alcott, 'Jevons' Paradox', Ecological Economics 54 (2005): 9-21. 
What disturbed most contemporary readers of his 1865 book on the coal question was the puzzling idea that, although technological progress was beneficial, it might hinder the conservation of coal reserves. In conjunction with the technological factor, Jevons factored in two more causes contributing towards ramping up the speed of solid fossil fuel exhaustion: population growth and the effects of growing affluence and rising average income. All three - technology, population and affluence - worked in the same direction, though technology was clearly the wild card in the evolution of society.

In order to forecast the pace of British coal consumption, Jevons attempted to demonstrate that all three factors evolved in a uniform geometrical ratio with uniform multiplication throughout uniform periods. Like an orderly yield of continuing progress, geometrical growth was not only as "necessary as a mathematical law' but a pattern of regularity characteristic of 'man and all living creatures'. ${ }^{41}$ Based on the sustainability of this progress, Jevons set the annual coal production growth rate at 3.5 per cent. As can be seen in Figure 2, while the previous forecasts advanced by the industrialist William George Armstrong had already cut the depletion gap thanks to his method of fixed linear increases (a growth rate of 2.75 million tons per year), the time before exhaustion was again shortened under Jevons' geometric law - by approximately 100 years relative to Armstrong's estimate (from 212 years to about 100 years).

The disparity between the two forecasts is depicted in Figure 2: whilst half of British recoverable coal would have been extracted by the 1940s according to the Jevons account, Armstrong predicted that only 20 per cent would have been removed by that time. The graph also charts the real time series of coal production in Britain, revealing that Armstrong's simple linear method came closer to the truth than Jevons' geometric law of enhanced progress, despite the industrialist's tendency to underestimate growth potential.

Regardless of the discovery of the 'rebound' or 'take-back' effect, Jevons' vision of omnipresent coal made him greatly overestimate the growth trend. Why were Jevons' forecasts so far from reality? Leaving aside how easy it is to be wise after the event, two reasons stand out as possible sources of bias in the author's judgment: firstly, there was a clear overstatement of the opportunities for new industrial applications associated with the belief that the clear superiority of coal-steam in terms of power capacity would swiftly replace the less powerful traditional energy carriers; secondly, Jevons was convinced that coal would prove the mainstay of contemporary civilisation and no other power source could ever be invented to replace it.

Whilst there was still a broad margin for thermodynamic improvements in coal-fuelled engines, other existing energy sources fell short of any secure future: electricity was encumbered by 'fallacious notions', 'miraculous effects' and all kinds of unattainable beliefs; wind power was uncertain and lacked capacity; the water wheel and turbine were not only rigidly set in fixed spots but were

41. Jevons, The Coal Question, p. 170. 


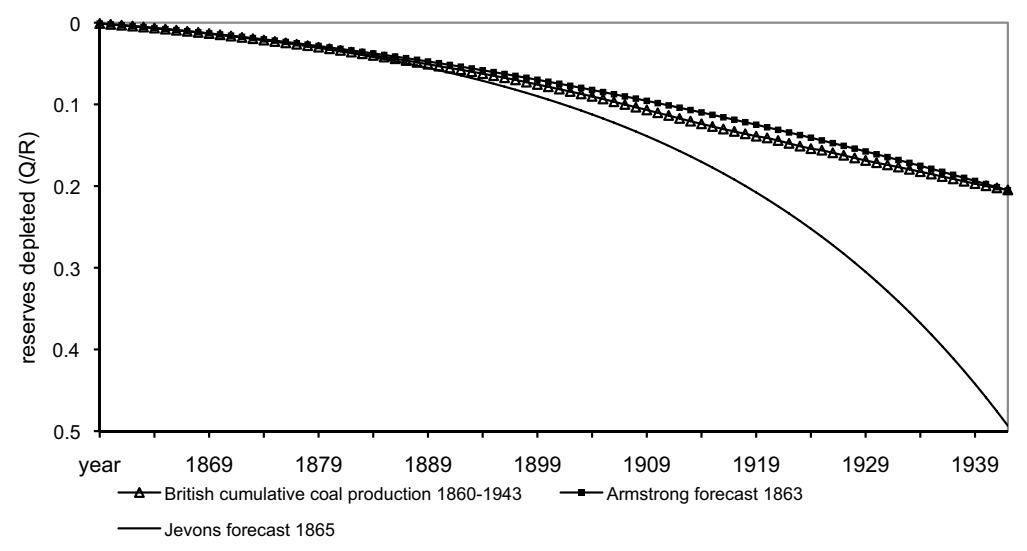

Figure 2. British coal exhaustion according to nineteenth century forecasts (1860-1943)

$(\mathrm{Q} / \mathrm{R})=$ Cumulative production forecasts/Recoverable coal reserves - UK 1861 Geological Survey; British cumulative coal production/Recoverable coal reserves - UK 1861 Geological Survey;

Sources: Edward Hull. The Coal-fields of Great Britain, their History, Structure, and Duration. With notices of the coal-fields of other parts of the world (London: Edward Stanford, 1861); William Stanley Jevons, The Coal Question: an Inquiry Concerning the Progress of the Nation and the Probable Exhaustion of our Coal Mines (London: Macmillan, 1866); Lozé (ed.) Charbons Britanniques et leur épuisement (Paris: Libraire Polytechnique Ch. Bérangeur éditeur, 1900); B.R. Mitchell, International Historical Statistics: Europe, 1750-1993 (London : Macmillan Reference/New York: Stockton Press, 1997); Department for Business Enterprise \& Regulatory Reform, 'Historical coal data: coal production, availability and consumption 1853 to 2007'. www.berr.gov.uk/files/file40592.xls Downloaded 7 July 2010.

also dependent on winter streams and reservoirs; peat and turf were too costly; sun could perhaps be collected someday, though the consequence of such a discovery would 'simply' be to 'destroy British industrial supremacy'. Finally, petroleum was 'solely a new way of pushing the consumption of coal', and was 'more likely to be an aggravation than a remedy'. ${ }^{42}$

To sum up, coal-based technology would rapidly seize the market share of traditional energy carriers and sustain long-term economic growth singlehandedly, since no other substitute could ever match its performance and efficiency. Hence, the mounting demand created by the geometrical growth of population, income and modern technology had to be supplied by a single resource. One may wonder whether Jevons' emphasis on the impossibility of substituting the existing power sources resulted from a theoretical framework borrowed from physics and based on the principle of conservation of energy:

42. Jevons, The Coal Question, pp. 140-168. 
coal was irreplaceable because one could not conceive of getting energy 'out of the vacant space' but only from natural sources that make use of oxygen to produce combustion, in such a way that the mechanical energy already resident in fossil fuels could be turned, or converted, into heat, light, chemical change or mechanical motion ${ }^{43}$ Under this framework, the most feasible future source was coal rather than oil, which, at the time, was exclusively used as lighting fuel in lamps. Another possibility is that the exclusion of everything but coal was due to the need to heighten the contrast between ever-changing economic progress on the one hand and the static and unalterable frame of natural conditions on the other. According to the logic of The Coal Question, energy resources were seen as a fixed stock, a stock handed down in advance and not dependent on human action. By locking the amount of physical resources into an immutable and non-substitutable aggregate, Jevons could define the role of coal as a constraint on British development, if not on overall human progress.

Working on the assumption that modern societies are torn between nonrenewable resources and boundless needs and desires, Jevons drew the paradigm of economic science as the optimal allocation of externally given scarce factors of production. Along this line of reasoning, 'scarcity' became a meaningful concept by playing down human inventiveness. Every element which could vary in the fixed stock of physical resources was thus downplayed: Jevons not only set aside the possibility of finding new coalfields, ignoring the probable reserves defined by the British Geological Survey ${ }^{44}$ but also expressed great doubts about the real chances of removing coal at depths of 4,000 feet since 'nobody would be so foolish as to suppose we could go to that depth' ${ }^{45}$ Moreover, Jevons clearly underestimated the chances of coming across new energy sources like hydroelectricity or solar energy which his contemporary, the industrialist William George Armstrong, had wisely considered and misjudged the recent take off of the petroleum industry on the other side of the Atlantic, as well as the feasibility of feeding reciprocating steam-engines with crude oil and fuel-oil.

In sum, we may certainly say that Jevons' analysis of the rebound effect and the price mechanism brought to light a fresh perception of the conditions that might foster coal depletion. However, his exclusive emphasis on a fixed stock of coal made him underestimate the effects of innovation and human ingenuity in changing a given set of initial conditions. By neglecting the potential for coal substitution, both through upgrading traditional technologies and the invention of new technologies, he made an upwardly biased forecast of coal consumption. Still more surprising, Jevons downplayed the key role of higher prices in driving supply and did not consider the spontaneous effect of resource adjustments through a 'scarcity rent' embodied in the final price. The omission

43. This hypothesis was raised by White, 'In the Lobby of the Energy Hotel', pp. 227-71.

44. Jevons, The Coal Question, pp. 19-20, 24, 47.

45. William Stanley Jevons, 'The probable duration of our coal seams', Glasgow Herald, September 6 1871, Issue 9885. 
of this sort of negative feedback effects of higher prices on slower resource depletion, though hardly understandable in hindsight, stems from the logic of proofing the scarcity thesis ${ }^{46}$.

\section{GEOLOGY FIGHTS BACK: THE EMBODIMENT OF PROBABLE RESERVES}

The new economic explanation for the inevitability of coal depletion and the revised forecasts left a trail of uneasiness in British society. Like an unwelcome and suddenly revealed truth, Jevons' ideas gave form to collective fears concerning coal scarcity and, most of all, to the decline that would necessarily ensue throughout the Empire. This was partly due to the psychological effects created by the long persistence of unsettling doubts concerning the size of coal reserves. However, it was also partly due to the repercussions caused by the debate, cutting across all sorts of social and institutional networks and coloured with distinct overtones: there was political discussion amongst parliamentary factions over the budget and the future of the nation; a business-technical discussion carried on by local elites about the future of industry; and a diplomatic reflection within the imperial administration about British positioning in international competition.

The parliamentary divide was triggered when William Gladstone, Chancellor of the Exchequer, subscribed to the Jevons thesis, turning the coal question into a matter of political dissension by considering that, inasmuch as fossil fuel reserves were being consumed at an enormous rate, the British government ought to pay off, or at least reduce, the National Debt before the time of their exhaustion. Liberal and Tory realignment along the National Debt split attracted widespread public attention to the coal question.

A second channel of dissemination was set in motion courtesy of the concerns of local upper-classes, businessmen and scientists, who took the task of re-examining the forecasts for coal depletion in their districts into their own hands. To mention just the meetings reported in the press, geological debates dedicated to the theme of regional scarcity were held at scientific societies in Staffordshire, Worcestershire, Scotland, North Wales, Derbyshire, the Bristol region, Northumberland in general and Newcastle-upon-Tyne in particular. ${ }^{47}$

46. The point was raised by Harold Hoteling in reply to conservationist claims over resource depletion in 1931. Harold Hoteling, 'The Economics of Exhaustible Resources', Journal of Political Economy 39 (1931): 137-75. We would like to thank the anonymous referees for Environment and History for bringing up this point.

47. 'Dudley and Birmingham Geologic and Scientific Society', 16 August 1862, Birmingham Daily Post, Issue 1269; 'The present working and future supply of coal in this district', 23 January 1864, Birmingham Daily Post, Issue 1732; 'Our probable supply of coal', 20 February 1864, Glasgow Herald, Issue 7525; 'Mr Gladstone on the coal resources of the country', 7 January 1865, The Preston Guardian, Issue 2792; 'Our coal supplies', 24 March 1870, Birmingham Daily Post, Issue 3644; 'Coal in the south of England', 26 August 1871, 
Finally, a third stream of inquiry was set into motion by the close watch on worldwide production and trade in coal. As aforementioned, the Foreign Office seized upon the available expertise of embassies and consular networks to grasp every scrap of data on coal mining, prices, exports, imports and the future potential of producing nations. In so doing, much of the institutional framework of the Foreign Affairs was reshuffled to serve the needs and ends of these diplomatic surveys.

Caught up in this web of social and political interests, Jevons' book was thrown starkly into the spotlight. Maybe in the afterthoughts of such success, the British economist might well have had occasions to remind himself of the popular saying that warns to 'be careful about what you wish for, because it might come true'. Jevons certainly sensed the looming counterattack and heard few voices rising in his defence. Within parliament, the prospects of industrial decline were increasingly targeted by critical members and by Gladstone's opponents. As indignation mounted, Gladstone was forced to comply with the appointment of a Royal Commission to investigate and to report on the quantity of coal available. Publicly, this amounted to the recognition that something might be profoundly wrong with the Jevons and Armstrong assessments. Quite naturally, the Commission arrayed some of the most avowed enemies of the depletion thesis, namely the copper-smelter and Deputy Lieutenant for Glamorgan, Hussey Vivian, and the colliery-owner from Sunderland, George Elliot, future president of the North of England Institute of Mining Engineers. It also kept Jevons on the outer fringes of the inquiry. ${ }^{48}$ In every respect, the stage seemed set for the rebuttal of the scarcity threat. And thus it proved. The reviewed estimates publicly released in 1871 (not without some prior leaks to the press) assured a comforting horizon of 360 years coal supplies, based on forecasts of lower population growth, lower consumption growth, larger workable physical reserves and larger probable reserves. ${ }^{49}$

Notwithstanding the political bias behind the scenes, the 1866-71 Coal Commission set new benchmarks in geological knowledge. For the first time, a methodology was tested out for quantitatively estimating the dimensions of undiscovered seams, turning the concept of 'probable reserves' into an operational, comprehensive and verifiable gauge. Departing from proven coalfields, the surveyors carried out systematic research to assess whether their geological boundaries were cut off from any other coalfields, or turned round to join, in a

The Bristol Mercury, Issue 4246; 'Northern Union of Mechanic Institutions', 2 August 1872, The Newcastle Courant, Issue 10310.

48. Michael V. White, 'A Revised Bibliography of Publications by W. Stanley Jevons', History of Economics Review 51 (2010): 106-28.

49. Report of the Commissioners appointed to inquire into the several matters relating to coal in the United Kingdom. House of Commons, Parliamentary Papers (London: George Edward Eyre and William Spottiswoode, 1871), Vol. I, II and III. For a clear summary of the 1866-1871 Commission see B.W. Clapp, An Environmental History of Britain since the Industrial Revolution (New York: Longman, 1994), pp. 152-56. 
continuous underlying superincumbent stratum, other separate basins. By means of hypotheses formulated over the boundaries of geological seams and their probable thickness, the Commission arrived at a figure of 56.2 billion tons of 'hidden' coal $\left(56.2 \times 10^{9}\right)$, which were added to the 90.2 billion tons of proven reserves. But it went still farther and advanced the estimate of 41 billion tons at depths greater than 4,000 feet, some of which lay in the undiscovered coalfields of southeast England..$^{50}$

Taken as a whole, the economic thesis of scarcity boosted geological research to unprecedented heights, leading in just a decade to the formulation of fresh classificatory schemes that coped with the uncertainty of coal reserves. Each degree of uncertainty was placed in a separate category, with a level of certainty deriving from the conditions describing the geological event. Capriciously, however, another turnaround was about to happen. The results of the Coal Commission were released in 1871, right in the midst of an upsurge in coal prices and financial turbulence. ${ }^{51}$ Once more, the evidence of experts was confronted by the counterevidence of business. The 'coal panic' unleashed the general fears of an age of commercial exhaustion, overshadowing much of the Report's content. Therefore, and in spite of the geological pledge that there was 360 years of secure supply, a new Select Committee 'to inquire into the causes of the present dearness and scarcity of coal' was again appointed by the House of Commons.$^{52}$ Only afterwards, in the $1880 \mathrm{~s}$, did the pessimistic view begin to recede, owing to the repeated restatement of larger geologic reserves and the downward trend in coal prices. Contemporaries also took note of the systematic divergences with Jevons' forecasts and concluded that reserves would certainly last longer than predicted.

Several factors strengthened the optimistic stance towards coal. At the close of the nineteenth century a spurt of investment in mining unveiled the potential of new coalfields located outside the core nations and developed mostly in countries of low mining production (in Southern and Eastern Europe, Africa and Asia). Simultaneously, large geological formations were also confirmed in Canada, China, Germany and Russia. Step by step, coal geology began to reveal the incidence of fossil fuels across the globe, filling in the blanks on the world map. At the same time as coal turned into a global resource, its substitution was eased by technological changes that took place in the shipping and railway sectors: the development of the first successful applications for pulverising crude oil and blowing it into a furnace in spray form provided a successful substitution for solid fossil fuels in steam-engines, allowing for the flexible switchover from

50. Report of the Commissioners appointed to inquire into the several matters..., Vol. II, pp. 413-526.

51. Church, The History of the British Coal Industry, pp. 50-5.

52. Report of the Select Committee on Coal, House of Commons, Parliamentary Papers (London: House of Commons, 1873). 
coal to oil. ${ }^{53}$ The effect of technological substitutability, together with more widespread proven reserves, boosted the prospects for long-term coal usage.

More relaxed consumption and a recognised safety margin for the next generations meant that the debate shied away from economic and technological theories and returned to the materialistic ground of geological appraisal. The crux of the matter was again the amount of physical reserves, irrespective of price movements or consumption trends. In the belief that the time was ripe for worldwide recognition of geological knowledge, the organising committee of the Twelfth International Geological Congress, scheduled for Toronto in 1913, challenged each participating nation to collect and submit evidence on the important topic of the world's supply of coal. ${ }^{54}$

Surveys were addressed to the heads of Geological Surveys around the world with instructions to classify their coal supplies according to both the economic feasibility of mining and coal quality. Thus, the stock of solid fossil fuels could be classified using a systematic typology, differentiating between 'actual', 'probable' and 'possible' reserves thus distinguishing between: (i) the quite reliable estimate of coal susceptible to recovery with the existing equipment from well-established or known reserves, and under existing operating conditions (actual or proven reserves) based on geological and engineering data; (ii) the quantity of coal which could reasonably be expected to exist and be recovered with the available technology and at an economically viable cost (probable reserves); and (iii) the total quantity of coal, whether or not recoverable with current technology and costs (possible reserves).

Despite good intentions, the procedures for gathering decentralised data did not run smoothly. Monitored only by provisional congress committees, the final assessment of coal reserves became a hotchpotch of varying criteria. Local terminologies based on historical usage and commercial practices bypassed the official categorisation framework, which made inter-country comparisons almost impossible. In some reports the figures for probable reserves included the actual and probable reserves, while in others they included the probable and possible reserves. The editors did warn readers that a 'large part of the coal included in the estimate would be very difficult to mine and generally the loss in mining would be great'. ${ }^{55}$ In fact, the main result of mixing proven and nonproven coal resources was to level the evaluation benchmark around the upper boundary of 'possible reserves', thus inflating the whole account with doubtfully

53. George W. Melville, Report of the U.S. Naval Liquid Fuel Board (Washington: Government Printing Office, 1904); F.B. Dunn, Industrial Uses of Fuel Oil (S. Francisco: Technical Publishing Company, 1916).

54. Gerard V. Middleton, 'The 12th International Geological Congress. Toronto, 1913', Episodes 30 (2007): 290301; Leon Dominian, 'The Coal Resources of the World: A Summary', Bulletin of the American Geographical Society 47 (1915): 761-66.

55. William McInnes, D.B. Dowling, and W.W. Leach, The Coal Resources of the World: An enquiry made upon the initiative of the Executive Committee of the Twelfth International Geological Congress, (Toronto-London: Morang \& Co.-Dulau \& Co, 1913), XVIII. 
exploitable forecasts. This expediency, used to bypass disparities among national surveys, explained how such a large figure was reached: 5 thousand billion $(5 \mathrm{x}$ $10^{12}$ ) tons of coal equivalent. Although this had little commercial significance, the outline for world reserves set by the Toronto Geological Congress lent its scientific weight to the public restatement of the security of supply. Industrial society would certainly not be crippled by the exhaustion of energy sources, at least not by coal exhaustion.

TABLE 1. The coal reserves estimation of 1913 and the ensuing world economic evolution (1914-2008) (in million tons of coal equivalent, tce).

\begin{tabular}{|c|c|c|c|c|}
\hline $\begin{array}{l}\text { (1) } \\
\text { Country (1913 } \\
\text { borders) }\end{array}$ & $\begin{array}{l}(2)^{*} \\
\text { Actual, probable and } \\
\text { possible coal reserves } \\
1913\end{array}$ & $\begin{array}{l}(3)^{*} \\
\text { Coal accumulated } \\
\text { production, } \\
1914-2008\end{array}$ & $\begin{array}{l}(4)^{*} \\
\text { Proved reserves } \\
\text { BP assessment } \\
2008 \\
\end{array}$ & $\begin{array}{l}(5) \\
(3+4) /(2)\end{array}$ \\
\hline United States & $2,658,438$ & 61,738 & 167,555 & 0.09 \\
\hline Canada & 814,423 & 2,753 & 5,085 & 0.01 \\
\hline China & 710,652 & 31,571 & 64,546 & 0.14 \\
\hline German Empire** & 247,593 & $22,362 * *$ & $5,788 * *$ & 0.11 \\
\hline Great Britain & 161,507 & 13,787 & 132 & 0.09 \\
\hline Russian Empire** & 144,099 & $26,590 * *$ & $141,249 * *$ & 1.16 \\
\hline France & 15,079 & 3,180 & 0 & 0.21 \\
\hline Other Nations & 350,883 & 30,826 & 114,687 & 0.41 \\
\hline World & $5,102,672$ & 143,855 & 352,005 & 0.14 \\
\hline
\end{tabular}

Notes:

* Country coefficients for anthracite, bituminous coal, and lignite conversions into tons of coal equivalent (tce) based on Bouda Etemad and Jean Luciani, World Energy Production, 1800-1985, Librarie Droz: Geneva, 1991, pp. xxv-xxvii.

** German Empire and Russian Empire: author's estimation based on the quoted bibliography.

Sources:

William McInnes, D.B. Dowling and W.W. Leach (ed.) The Coal Resources of the World: an enquiry made upon the initiative of the Executive Committee of the Twelfth International Geological Congress (Toronto / London: Morang \& Co. / Dulau \& Co,1913); B.R. Mitchell, International Historical Statistics: Europe 1750-1993 (London: Macmillan Reference/New York: Stockton Press, 1997); Bouda Etemad and Jean Luciani, World Energy Production, 1800-1985 (Librarie Droz: Geneva, 1991); Amos Salvador, Energy: A Historical Perspective and 21st Century Forecast (Tulsa, Oklahoma: American Association of Petroleum Geologists, 2005); Victor H. Winston, 'The Polish Bituminous Coal-Mining Industry', American Slavic and East European Review 15 (Fall 1956): 38-70; Department for Business Enterprise \& Regulatory Reform, 'Historical coal data: coal production, availability and consumption 1853 to 2007', http://www.berr.gov.uk/files/file40592.xls Accessed 7 July 2010; US Energy Information Administration- EIA, http://www.eia.doe.gov/emeu/ aer/coal.html Accessed May-June 2010; BP Statistical Review of World Energy, June 2009, http://www.bp.com/liveassets/bp_internet/globalbp/globalbp_uk_english/reports_and_publications/statistical_energy_review_2008/STAGING/local_assets/2009_downloads/statistical_review_of_world_energy_full_report_2009.pdf Accessed July 2010. 
The value of the 1913 Geological Congress estimates can be assessed if we compare the amount of actual, probable and possible reserves given at that time with the current state of knowledge. Column 2 of Table 1 shows the assessment for selected countries and the total amounts of world reserves from the 1913 perspective. The next depicts how much coal has since been produced (column 3 cumulative production from 1914 to 2008) while column 4 shows the 2008 assessment of proven reserves. All data was recalculated according to 1913 political frontiers with the different thermal contents of coal in each country translated into a common unit: the ton of coal equivalent (tce). Tce is a standard representation of 1,000 kilograms of the best quality coal in calorific terms so that one ton of substandard types, for example bituminous coal, sub bituminous or lignite, are converted across a range of 0.81 to 0.32 tons of coal equivalent (tce). Likewise, one ton of top-grade anthracite is equal to almost one ton of coal equivalent.

The data presented in Table 1 highlight two issues: firstly, all the coal that has been used plus the coal that remains today as guaranteed future stock, totals about 14 per cent of what was once estimated as possible reserves (Table 1, column 5). This suggests that the cushion set in place at the 1913 Toronto Congress greatly exceeded the proven recoverable and economically viable reserves using 2008 technologies. Only a tiny fraction of the possible coal reserves has been spared following a century of overwhelming economic growth, which throws the comforting dimension of the Geologists' report before World War I into perspective.

Secondly, some figures were clearly more flawed than others, reflecting basic national asymmetries in geological knowledge and state capacities to manage the whole territory and also varying levels of industrial development. The Russian Empire's underestimation of reserves was particularly striking as more coal is in the process of being extracted (Table 1, columns 3 and 4) than geologists had formerly thought 'possible' (Table 1, column 2). In terms of misjudgment, Russia played the role of the world's sleeping giant, something that might be explained by the historical concentration of coal mining at the time in the European part of Imperial Russia (notably in the Donets basin) and its disregard for other regions that later proved to be the jewels of Russian reserves - the harsh Siberian basins of Kuzbass, Lena, Tunguska and Irkutsk, the Urals basins and the untapped basin of Pechora in north-eastern European Russia. ${ }^{56}$

Nations with overvalued reserves like Canada and Britain were at the other extreme. Only a small part of the total possible coal reserves defined in 1913 proved recoverable using contemporary technologies and cost structures (Table 1, columns 3 and 4). Moreover, owing to high extraction costs both countries have already passed their historical peaks of production. In these cases the decline in throughput was not caused by a depleting resource base but by the

56. Ian F. Elliot, The Soviet Energy Balance. Natural gas, other fossil fuels and alternative power sources (New York: Praeger Publishers, 1974), pp. 122-56. 
price competition from other domestic and imported sources of energy. Such evolution contrasts sharply with the increasing amounts of coal being extracted annually in the United States and particularly in China.

\section{CONCLUSIONS: NOTABLE EXCEPTIONS AND ACCRUED USAGE}

To sum up, the more the debate about depletion moved away from the British perspective, the more the outlook for coal supply improved. Globally, the assessment of reserves took on a different appearance following the development and business expansion of new coalfields and in defense of imperial supremacy: whilst coal resource estimates in continental Europe and the United States were driven by investments in regional economic expansion, concern about the nation's economic future was the driver in Great Britain. British leaders viewed the linkage between coal and the empire as the mainstay of their strategic clout, which was then consolidated through trade networks, industrial advantage, shipbuilding industries and naval power. More than a commodity, what was at stake was a string of economic interdependencies with repercussions for the British way of life. There was such anxiety about coal's interlocking effects that the slightest sign of disturbance could escalate into sweeping policy issues. Irrespective of the different political positions of economists and geologists, they both shared the view that industrial ascendancy and world supremacy was closely bound up with coal. ${ }^{57}$ The issue affected not only the realm of British identity but also, one way or another, the core of social and political interests.

The existence of powerful propagation mechanisms, cutting across political, business and administrative networks, explains why the mood of alarm pervading significant sectors of the ruling classes occurred contrary to all significant evidence. In effect, the 1850 s were a period marked by a steady increase in coal consumption, heightened by new applications in iron and steel manufacture, urban gas production, steamships and railways, and mounting residential usages. ${ }^{58}$ The wave of technological novelties heralded a 'brave new world' with uncertain contours. Under these circumstances, the first signs of exhaustion in coal fields that had long since passed into mature phases of production, unleashed generalised fears. Ignorance about the amount of reserves and coal's interlocking political-and economic effects turned the exceptional into the exemplar. In this sense, political anxiety was more driven by the pace of economic growth and technological development than by any commercial fears of real coal shortage: anxiety was grounded in abundance. The social function of the British Geologi-

57. This relationship was recently called into question by contemporary econometric historians. N.F.R. Crafts and C.K. Harley, 'Output Growth and the Industrial Revolution: A Restatement of the Crafts-Harley View', Economic History Review 45 (1992): 703-30; Clark and Jacks, 'Coal and the Industrial Revolution': 39-72.

58. Church, The History of the British Coal Industry, p. 19, table 1.3. 
cal Survey was precisely to gauge the weighting of the exceptional depleted pits against the full potential of the mining industry. In so doing, geologists invented the concept that coal reserves are not bound by visible resources, but rather include possible untapped reserves.

After the rebuttal of geological pessimism by demonstrating that depleted pits in the country were the exception and not the rule, and that more coal was still available to be tapped into, a second wave of concern loomed and was again based on an exaggerated worst-case scenario. The key point was the salience of coal in modern industrial societies, its indispensability and the fact that the price mechanism fostered demand in a geometrical ratio. Whatever the geological basis, the market mechanism would unremittingly steer the course of events towards 'commercial exhaustion' (scarcity reflected in higher prices) and afterwards towards physical depletion. This second version of forestalled anxiety rested on the premise of technological evolution dependent on a single power source, turning coal into an indispensable element throughout society and therefore easily exhaustible. The exclusive emphasis on a fixed stock of coal ruled out any possible positive impact from the effects of innovation and human ingenuity on changing a given set of initial conditions. Indeed, this was the groundwork out of which the 'scarcity' concept surfaced.

Political, economic and social anxiety changed the awareness of fossil fuel finiteness and, more fundamentally, changed the very concept of energy reserves. The looming uncertainty of the 1860 s and 1870 s paved the way for new probabilistic assessments of mineral patrimony. Geological Surveys started reckoning in the coal left behind in open pits, still undiscovered coal and the coal that could be possibly extracted were new technologies invented in the future. All these mineral parcels added up to different categories, namely existent, probable and possible reserves. More parcels and more categories meant, in turn, extra buffers that stretched the lifespan of coal reserves before depletion. From this perspective, the Jevons postulate of a given fixed asset of coal reserves opened up a major controversy, as his idea was at odds with ongoing developments in geological knowledge. What is more, the threat of depletion, set forth by the theoretical mechanism of the rebound effect, had the practical consequence of stepping up geologic categorisation and quantification of uncertain energy reserves. Whereas economic science posited presumptive evidence, geological practice was already utilising probabilistic evidence (evidence about the circumstances and consequences of geological events). However, perhaps the most important point to stress is that the outstanding progress made in the domain of gathering such information remained almost unnoticed: in the face of contradictory information, and different estimates for depletion, fears about scarcity seemed to have gained in strength, rather than disappeared.

Not surprisingly, the country that brought industrial coal into the world was also that which first raised the possibility that this energy source could run out. In some sense, eschatological fear was the upshot of Britain's head start and 
its leadership in consumption, industrial usage and exports. Other nations saw the social and economic function of estimating natural resources as a frontier possibility, rather than from the viewpoint of being a reachable limit. The globalisation of geological estimates at the 1913 Toronto Congress confirmed prior suggestions that Britain's undisputed primacy in world exports might not correspond to its position as the best endowed nation (Table 1). ${ }^{59} \mathrm{As}$ far as coal was concerned, the future belonged to the largest territorial countries like the United States, Canada and China. Russia was mistakenly categorised among the secondary ranks of energy powers.

Core themes in ecological thinking, such as the exhaustion of natural resources, the rebound effect and the limits to economic growth, came out into the open through discussion of the coal question. Overall, this was a period of increasing ecological awareness, ${ }^{60}$ in which the future 'backfired' into the present. It was a period in which both individuals and governments developed ideas and concepts to think strategically, that is, to attach more importance to rewards to be collected in the distant future than to those enjoyed in the present. Seen from this perspective, the coal question inaugurated an epoch in which natural resources began to be envisioned with a 'low rate of time discounting'. ${ }^{61}$

59. League of Nations International Economic Conference, Memorandum on Coal, (Geneva: League of Nations, 1927), Vol. I, pp. 27-9.

60. On the linkages between Jevons and environmental thinking, see Brett Clark and John Bellamy Foster, 'William Stanley Jevons and The Coal Question: An Introduction to Jevons's "Of the Economy of Fuel", Organization and Environment 14 (2001): 93-98.

61. For the implications of the concept of 'low rate of time discounting' see Jon Elster, Explaining Social Behavior (Cambridge: Cambridge University Press, 2007), pp. 114-22. 
